\title{
MICROPROPAGAÇÃO DE BANANEIRA "PRATA" ATRAVÉS DE CULTIVO IN VITRO DE ÁPICES VEGETATIVOS
}

\author{
Padmaja Haridasan 1
}

Linda S. Caldas 2

Recebido em 20.07.88. Aceito em 01.06.89.

RESUMO - Ápices vegetativos de mudas de 2 a 4 mêses de idade foram cultivados no meio MS com $30 \mathrm{~g} / 1$ de sacarose e $22 \mu \mathrm{M}$ benzilaminopurina. Após 8 a 10 semanas, foram produzidos uma ou duas gemas laterais; a subcultura destas no mesmo meio produziu até 10 gemas após 6 a 10 semanas. A maior taxa de multiplicação em subculturas successivas foi de 40 plântulas novas por explante; a taxa de multiplicação média foi de 10 gemas novas por explante em 8 semanas. $O$ enraizamento ocorreu no mesmo meio mas um melhor enraizamento foi observado nos meios diluidos pela metade da concentração de MS em presença de $1 \mu \mathrm{M}$ AIB. As plântulas de diferentes subculturas transplantadas no campo apresentaram um crescimento mais uniforme e mais vigoroso do que as mudas tradicionais da mesma variedade. $\mathrm{O}$ sistema mostrou ser viável em escala comercial.

Palavras-chaves: Musa spp., bananeira "prata", cultura de tecidos, multiplicação clonal.

\begin{abstract}
Vegetative shoot tips from 2 to 4 month old suckers of banana cv. "Prata" were grown on MS medium with $30 \mathrm{~g} / 1$ sucrose and $22 \mu \mathrm{M}$ benzylaminopurine. After 8 to 10 weeks, one or two lateral buds were produced; subculture of these on the same medium produced up to 10 buds after 6 to 10 weeks. The highest multiplication factor observed in subsequent subcultures was 40 new palntlets per explant; the average multiplication factor was 10 buds per explant in 8 weeks. Rooting occurred on the same medium but better rooting was achieved on medium diluted to halfstrength MS with $1 \mu \mathrm{M}$ indole-butyric acid. Plants obtained from different generations of subculture, when transplanted to the field, showed more uni-
\end{abstract}

1 - Bolsista do CNPq, Depto. de Biologia Vegetal, Universidade de Brasília, C.P. 153081 CEP 70919 Brasília, DF.

2 - Bioplanta Tecnologia de Plantas Ltda., C.P. 1141, CEP 13100 Campinas, SP. 
form and more vigorous growth than traditional planting material of the same variety. The system is viable for commercial scale multiplication.

Key words: Musa spp., banana cv. "Prata", tissue culture, micropropagation.

\section{Introdução}

A produção de mudas de bananeiras é um processo muito lento por causa da dominância apical. No caso de cultivares novos e de clones limpos de patógenos, a maneira convencional de propagação é um dos fatores limitantes no estabelecimento de novos bananais.

O desenvolvimento de técnicas para a micropropagação de bananeiras é de importância no país uma vez que o Brasil é o maior produtor mundial de bananas. Em vários outros países produtores, a micropropagação tem se estabelecido como a técnica preferida para a produção de mudas em escala comercial (Hwang et al. 1984, Oglesby \& Griffis 1986). Cita-se as vantagens de obter mudas livres dos patógenos Fusarium oxysporum cf. cubense (mal-de-Panama), broca da bananeira, nemotoides e, com a devida indexação, o virus mosaico de pepino (Berg \& Bustamente 1974). Outras vantagens das mudas produzidas in vitro que apareceram em plantios em escala comercial incluem a facilidade de plantio (Oglesby \& Griffis 1986), a precocidade e maior uniformidade de colheita (Hwang et al. 1984).

A micropropagação de Musa spp. foi investigada por vários autores nos últimos anos (Ma \& Shii 1972, Guzman et al. 1980, Vessey \& Rivera 1981, Swamy et al. 1982/83, Cronauer \& Krikorian 1984 a, b, Hwang et al. 1984, Vuylsteke \& Langhe 1985, Banerjee \& Langhe 1985, Wong 1986). Entre estes autores, apenas Vuylsteke \& Langhe (1985) e Banerjee \& Langhe (1985) citaram o cultivo in vitro de ápices vegetativos de bananeira "Prata", apresentando dados sobre as taxas de multiplicação em sucessivas subculturas. Os outros autores relataram, principalmente, sucesso na fase de regeneração de outras variedades. Vuylsteke \& Langhe (1985) e Banerjee \& Langhe (1985) constataram que a taxa de multiplicação de bananeira "Prata" era menor do que de outras variedades testadas.

A banana "Prata" é uma das variedades mais importantes no Brasil, portanto, o objeto deste trabalho foi de desenvolver técnicas de cultura de ápices vegetativas in vitro para obtenção de mudas sadias da cv. "Prata" em escala comercial.

\section{Material e Métodos}

Mudas de bananeira "Prata" de 2 a 4 mêses de idade, cultivadas na Estação Experimental de Biologia da Universidade de Brasília, no Lago Norte de 
Brasília e no PAD-DF, foram utilizadas como fonte de explantes. Ápices ainda cobertos por algumas bases foliares foram retirados de rebentos no campo e desinfectados com solução comercial de hipoclorito de sódio $(0,8 \%$ de cloro ativo na concentração final) por 15 minutos. Ápices com $5 \mathrm{~mm}$ de comprimento foram inoculados no meio de cultura.

O meio básico utilizado continha sais (macro e micronutrientes) e vitaminas segundo Murashige \& Skoog (1962), com sacarose (3\% p/v) e agar (0,5\% $\mathrm{p} / \mathrm{v})$. $\mathrm{O}$ pH foi ajustado a 5,8 anteriormente à adição de agar. Foram testados os hormônios BAP (benzilaminopurina), cinetina, AIA (ácido indolil-acético), 2,4-D (ácido 2,4-diclorofenoxiacético) e AIB (ácido indolbutirico) em diferentes concentrações, com ou sem água de coco, com base nas combinações citadas na literatura para outras cultivares de banana (Tabela 1). As culturas foram mantidas em três fotoperíodos: 12,16 e 24 horas de luz, todos na mesma temperatura de $28^{\circ} \mathrm{C}$.

Os meios, números 1 a 7 (Tabela 1), foram testados na fase de isolamento dos ápices oriundos de mudas de campo ( 6 ápices por tratamento- em três repetições independentes, sendo utilizadas cada vez mudas procedentes de diferentes locais. Os meios 3, 8, 9 e 10 (Tabela 1), foram comparados na segunda subcultura, na fase de multiplicação. Foi testado o meio 3 (Tabela 1) nas formas sólidas e líquida, após a terceira subcultura, alternando as duas formas ou utilizando apenas uma das formas por várias subculturas sucessivas.

Para promover o enraizamento, as plântulas com 2 a 4 folhas foram transferidas para um novo meio básico diluido pela metade da concentração do meio MS com $1 \mu \mathrm{M}$ de AIB. Após o enraizamento, essas plântulas foram transplantadas para copos com vermiculita e solo esterilizado, em uma proporção de 1:1, e foram mantidas num fotoperíodo de 12 horas de luz no ambiente do laboratório para aclimatação. Quando apresentaram 8 ou 9 folhas e uma altura acima de $20 \mathrm{~cm}$, as mudas foram transplantadas para sacos plásticos contendo terra com esterco. Após três a quatro semanas em sacos, as mudas foram transplantadas para o campo.

\section{Resultados e Discussão}

Não houve desenvolvimento do ápice em nenhuma das repetições nos meios testados na fase de isolamento (Tabela 1), com a exceção do meio 3. Nos demais meios, dentro de poucos dias, os explantes e, em consequência, os meios, se tornaram totalmente escuros. No tratamento 3 , com $22 \mu \mathrm{M}$ BAP, todos os explantes, das três fontes diferentes de mudas, desenvolveram-se. Os explantes inicialmente aumentaram de volume e, no final de 4 semanas, a maioria dos explantes já apresentava 3 ou 4 folhas. Foi observado neste estágio um escurecimento do meio e o início de necrose das superfícies do explante em contato com o meio. Os tecidos internos dos explantes não foram afetados. 
As partes necróticas dos explantes foram retiradas e os mesmos transferidos para meio fresco, onde continuaram crescendo vigorosamente. Em alguns casos, os explantes produziram uma ou duas gemas laterais após 4 a 6 semanas (Figura 1A). O desenvolvimento dos explantes foi o mesmo no meio $3 \mathrm{em}$ todos os três fotoperíodos testados.

Após 4 a 6 semanas, cada uma das gemas foi separada dos explantes e repicada para o mesmo meio. $\mathrm{O}$ crescimento foi mais rápido do que na fase de isolamento. As culturas apresentaram dois tipos de multiplicação de gemas após 6 a 8 semanas: (1) proliferação de estruturas como bulbilhos e (2) proliferação de gemas. No caso dos bulbilhos, cada explante tinha vários pontos de crescimento ou pontos meristemáticos (Figura 1B). No caso de proliferação de plântulas, cada explante produziu 2 a 10 plântulas novas (Figura 1C). Alguns explantes apresentaram os dois padróes morfogenéticos simultaneamente (Figura 1D). Iniciação de necrose nesta subcultura ocorreu com uma intensidade menor do que na primeira fase de estabelecimento das culturas. Entretanto, foi feita a nova subcultura após 4 semanas para evitar o escurecimento do meio. $\mathrm{O}$ melhor crescimento dos explantes nesta primeira subcultura ocorreu em fotoperíodo de 12 horas. Não houve nenhum enraizamento dos explantes nesse meio, nessa subcultura.

Os meios, números 8,9 e 10, foram testados juntamente com o meio 3 (Tabela 2) na fase de multiplicação, para otimizar a concentração de BAP e avaliar o efeito da água de coco na multiplicação de gemas. A taxa de multiplicação (Tabela 2) foi bem menor no meio com $9 \mu \mathrm{M}$ BAP $(4,5$ gemas novas por gema individual inoculada, em 8 semanas) do que no meio com $22 \mu \mathrm{M}$ BAP (10 gemas novas). As gemas também se necrosaram mais rapidamente no meio com $9 \mu \mathrm{M}$ de BAP. Não houve nenhuma diferença entre tratamentos com 22 $\mu \mathrm{M}$ de BAP e com $44 \mu \mathrm{M}$ de BAP em número de gemas novas. Portanto, uma concentração de $22 \mu \mathrm{M}$ de BAP parece ser mais apropriada para multiplicação de bananeira "Prata", coincidindo com os resultados de vários outros autores para outras cultivares (Teixeira \& Ferreira 1983, Cronauer \& Krikorian 1984b). A taxa média de multiplicação estabilizou-se num valor médio de 10 novas gemas por explante em 8 semanas nas subculturas subsequentes (até a sexta subcultura); o mínimo de 2 novas gemas e o máximo de 22 por explante na segunda subcultura (Tabela 2), aumentaram para um mínimo de 4 e um máximo de 40 nas subculturas subsequentes.

Um dos motivos para não utilizar altas concentrações de BAP nos meios de multiplicação é a inibição do alongamento da parte aérea. Não observamos tais efeitos em nossos estudos.

Esta taxa de multiplicação foi maior do que as obtidas por Banerjee e Langhe (1985), provavelmente por causa da menor concentração de BAP $(0,8$ $\mu M)$ utilizada por esses autores. Vuylsteke e Langhe (1985) não apresentaram o valor médio da taxa de multiplicação conseguida com banana "Prata" mas os mínimos e máximos (2-11 na segunda subcultura e 9-16 na terceira subcultura) 
foram semelhantes àqueles observados no presente trabalho. Eles utilizaram o meio básico do Murashige \& Skoog (1962) com $10 \mu$ M BAP. Como foi relatado por estes autores, obteve-se, também, gemas múltiplas em $100 \%$ dos casos. Não se observou nenhuma redução na taxa de multiplicação até a sexta geração.

Oglesby \& Griffis (1986) utilizaram água do coco no meio para a cv. "Grande Naine" mas, no meio com $22 \mu \mathrm{M}$ BAP, não aumentou a taxa de multiplicação da banana "Prata" (Tabela 2), nem melhorou o estado fisiológico das plântulas.

Foram utilizados meios líquidos alternados como meios sólidos para melhorar o crescimento de explantes, a partir da terceira subcultura. Essa transferência para meio líquido foi feita após 4 semanas em meio sólido, sem separar as gemas presentes no explante. As culturas foram mantidas no meio líquido por mais 4 semanas antes de avaliar a multiplicação. Os resultados obtidos com três sequências de meios (i. e., só meio sólido, meio sólido alternado com meio líquido, e só meio líquido nas subculturas sucessivas), mostram que a alternância de meios sólidos e líquidos é melhor para a multiplicação e o crescimento de gemas de bananeira "Prata".

As plântulas produziram 3 a 4 raíses no meio básico diluido pela metade de $1 \mu \mathrm{M}$ de AIB após um mês. A partir da terceira subcultura, ocorreu enraizamento de plântulas no meio 3, sólido e líquido (Figura 1F).

Quando foram transferidas para copos com vermiculita e solo esterilizado, as mudas cresceram bem e produziram um total de 8 a 9 folhas em 5 a 6 semanas, com $20 \mathrm{~cm}$ de altura e um bom desenvolvimento do sistema radicular (Figura 2A). Nesta fase, as mudas foram transplantadas para sacos com terra adubada. As mudas cresceram rapidamente, atingindo $80 \mathrm{~cm}$ de altura em 3 meses, quando foram transplantadas para o campo. $\mathrm{O}$ crescimento no campo foi vigoroso.

Mudas oriundas da segunda, terceira e quarta subculturas foram transplantadas para o campo, onde apresentaram um crescimento mais uniforme e uma taxa de crescimento superior ao das mudas comuns da mesma variedade (Figura 2B). As plantas oriundas da segunda subcultura começaram apresentar rebentos dentro de dois meses após o plantio, com até cinco rebentos dentro de três meses. Elas alcançaram uma altura média de $1,96 \mathrm{~m}$ e circunferência na base de $64 \mathrm{~cm}$, com 19 folhas após quatro meses. Entre 14 mudas da segunda subcultura, 14 da terceira subcultura e 100 da quarta subcultura transplantadas no campo, não houve nenhum caso de mortalidade.

Assim é possível obter milhares de mudas no prazo de um ano através da regeneração e multiplicação in vitro de um explante de ápice vegetativo de bananeira "Prata" pelo método descrito neste trabalho. 


\section{Referências Bibliograficas}

BANERJEE, N. \& LANGHE, E. de. 1985. A tissue culture technique for rapid clonal propagation and storage under minimal growth conditions of Musa (Banana and plantain). Plant Cell Reports 4: 351-354.

BERG, L. A \& BUSTAMANTE, M. 1974. Heat treatment and meristem culture for the production of virus-free bananas. Phytopath - 64: 320-322.

CRONAUER, S. S. \& KRIKORIAN, A. D. 1984a. Rapid multiplication of bananas and plantains by in vitro shoot tip culture. HortSci 19: 234-235.

CRONAUER, S. S. \& KRIKORIAN, A. D. 1984b. Multiplication of Musa from excised stem tips. Ann Bot. 53: 321-328.

GUZMAN, E. V. de, DECENA, A. C. \& UBALDE, E. M. 1980. Plant regeneration from unirradiated and irradiated banana shoot tip tissues cultured in vitro. Phil. Agric. 63: 140-146.

HWANG, S. C., CHEN, C. L., LIN, J. C. \& LIN, H. L. 1984. Cultivation of banana using plantlets from meristem culture. HortSci. 19: 231-233.

KRIKORIAN, A. D. \& CRONAUER, S. S. 1984. Banana. In W. R. Sharp, D. A. Evans, P. V. Ammirato \& Y. Yamada (eds.) Handbook of Plant Cell Culture, vol. 2. Macmillan Publ. Co., Nova York, p. 327-348.

MA, S. S. \& SHII, C. T. 1972. In vitro formation o adventitious buds in banana shoot apex following decapitation. J. Hort Sci China 18: 135-142.

MURASHIGE, T. \& SKOOG, F. 1962. A revised medium for rapid growth and bioassays with tobacco tissue cultures. Physiol-Plant. 15: 473-497.

OGLESBY, R. P. \& GRIFFIS, J. L., JR. 1986. Commercial in vitro propagation and plantation crops. In R. H. Zimmerman, R. J. Griesbach, F. A. Hammerschlag \& R. H. Lawson (eds.) Tissue Culture as a Plant Production System for Horticultural Crops. Martinus Nijhoff Publ., Dordrecht, p. 253-258.

SWAMY, R. D., RAO, N. K. S. \& CHACKO, E. K. 1982/83. Tissue culture propagation of banana. Sci Hort. 18: 247-252.

TEIXEIRA, J. B. \& FERREIRA, F. R. 1983. Cultura de meristema de banana "Maçâ" e indução de brotaçōes laterais, visando a multiplicação vegetativa. Resumos IX Reunião de Soc. Latino-Americano de Fisiologia Vegetal, Viçosa, MG, p. 45.

VESSEY, J. C. \& RIVERA, J. A. 1981. Meristem culture of bananas. Turrialha 31: 162-163.

VUYLSTEKE, D. \& LANGHE, E. de. 1985 . Feasibility of in vitro propagation of bananas and plantains. Trop Agric. (Trinidad) 62: 323-328.

WONG, W. C. 1986. In vitro propagation of banana (Musa spp.): initiation, proliferation and development of shoot-tip cultures on defined media. Plant Cell Tiss. Organ Cult. 6: 159-166. 
Micropropagação de bananeira "Prata" ...

TABELA 1 - Composição de meios utilizados no isolamento de ápices vegetativos e bananeira "Prata".

\begin{tabular}{ccccccc}
\hline $\begin{array}{c}\text { Trata- } \\
\text { mento }\end{array}$ & $\begin{array}{c}\text { BAP } \\
\mu \mathrm{M}\end{array}$ & $\begin{array}{c}\text { Cinetina } \\
\mu \mathrm{M}\end{array}$ & $\begin{array}{c}\text { AIA } \\
\mu \mathrm{M}\end{array}$ & $\begin{array}{c}2,4-\mathrm{D} \\
\mu \mathrm{M}\end{array}$ & $\begin{array}{c}\text { AIB } \\
\mu \mathrm{M}\end{array}$ & $\begin{array}{c}\text { Água de coco } \\
(\mathrm{m} 1 / 1)\end{array}$ \\
\hline & & & & & & \\
1 & 2,2 & 0 & 5,7 & 0 & 0 & 0 \\
2 & 4,4 & 0 & 2,9 & 0 & 0 & 0 \\
3 & 22,0 & 0 & 0 & 0 & 0 & 0 \\
4 & 44,0 & 0 & 0 & 0 & 25 & 100 \\
5 & 0 & 4,6 & 0 & 2,3 & 0 & 0 \\
6 & 0 & 4,6 & 0 & 9,0 & 0 & 0 \\
7 & 0 & & 0 & 23,0 & 0 & 0 \\
\hline
\end{tabular}


TABELA 2 - Efeitos de concentração de BAP e de água de coco na taxa de multiplicação de explantes de bananeira "Prata", na segunda subcultura.

\begin{tabular}{ccccc}
\hline Tratamento & $\begin{array}{c}\text { BAP } \\
\mu M\end{array}$ & $\begin{array}{c}\text { Água de coco } \\
(\mathrm{m} 1 / 1)\end{array}$ & $\begin{array}{c}\text { Taxa de multiplicação } \\
\text { (Gemas novas/8 semanas) }\end{array}$ & \\
\hline & & & Média & Min/Max \\
3 & 22,0 & 0 & 10,0 & $2 / 22$ \\
8 & 9,0 & 0 & 4,5 & $2 / 10$ \\
9 & 22,0 & 100 & 9,6 & $2 / 18$ \\
10 & 44,0 & 0 & 4,2 & $2 / 8$ \\
& & & & \\
\hline
\end{tabular}




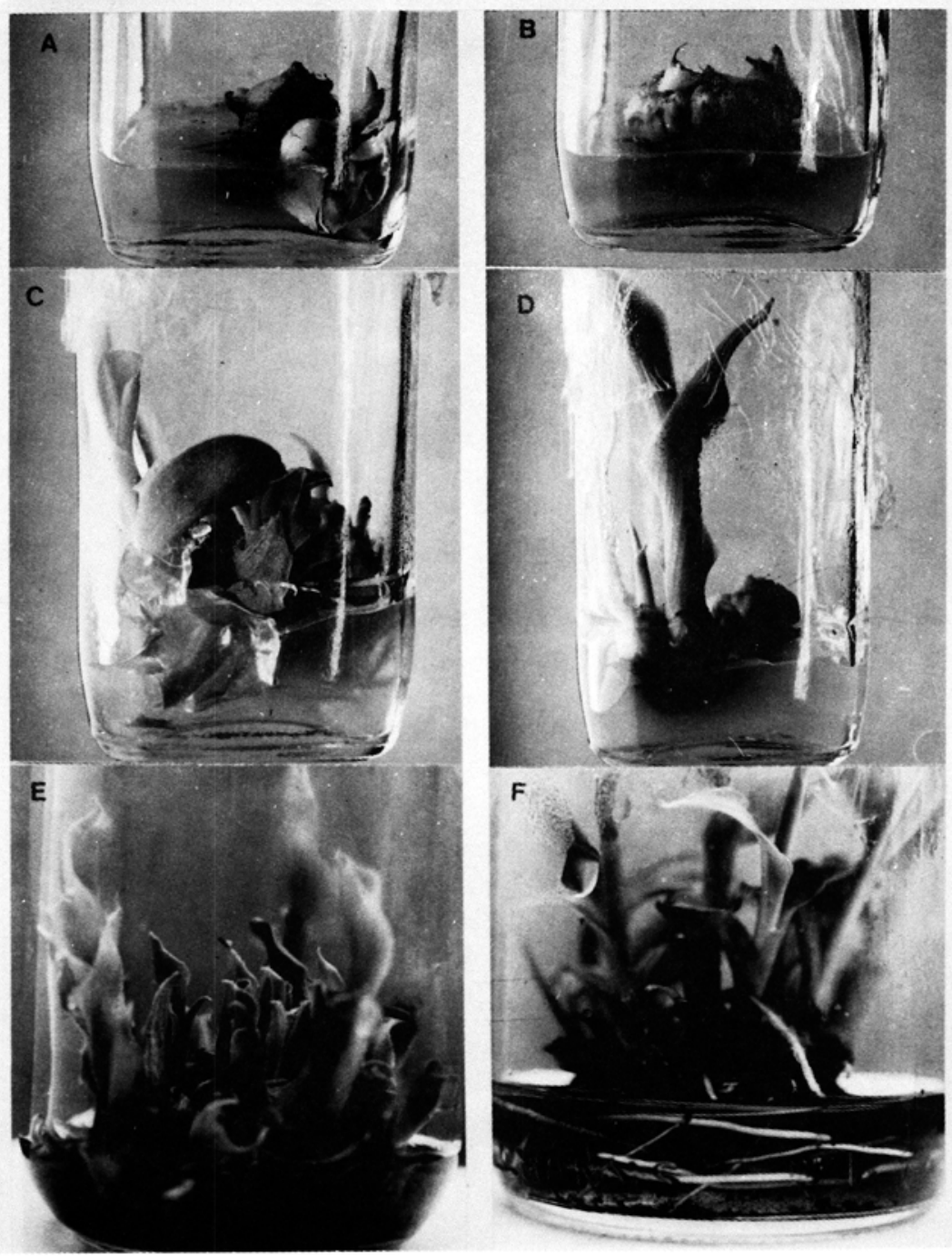

FIGURA 1 - Diferentes estágios de regeneração de plantas através de cultivo $n$ vitro de ápices vegetativos de bananeira "Prata". A - Explantes no meio de regeneração 10 semanas após inoculação. B - Produção de bulbilhos na primeira subcultura. C - Produção de plantas na primeira subcultura. D - Produção de bulbilhos e plantas no mesmo explante na primeria subcultura. F - Enraizamento de plantas da quarta subcultura no meio de multiplicação. 

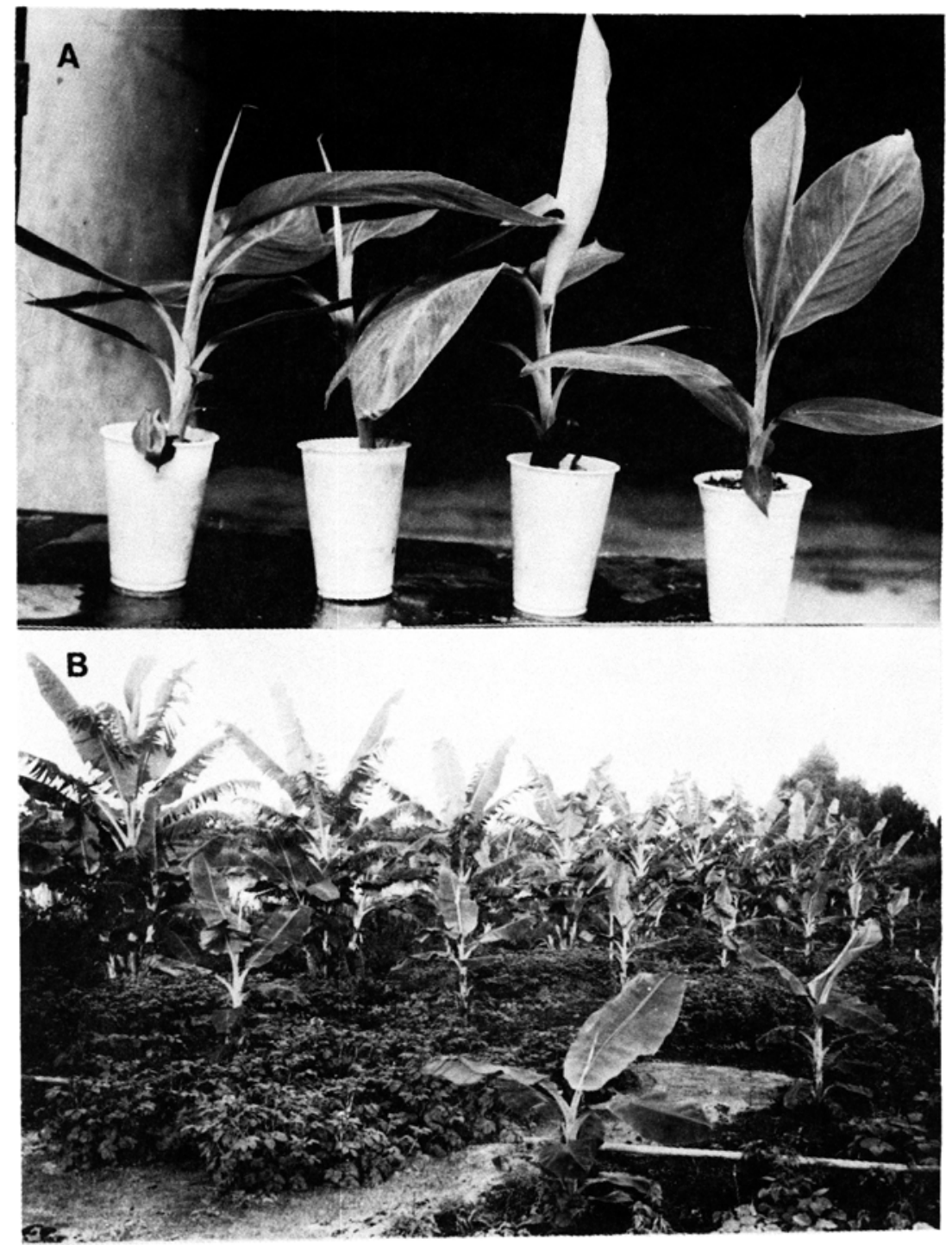

FIGURA 2 - Estabelecimento de plantas oriundas de cultivo in vitro de ápices vegetativos de bananeira "Prata". A - Em mistura de vermiculita e solo. B - No campo na Estação Experimental de Biologia da Universidade de Brasília: mudas com cinco (à esquerda), três (no meio) e dois (à direita) mêses de idade após o transplante. 